\title{
Aldersrelatert hørselstap: En kort oppsummering av resultater fra Hørselsundersøkelsen i Nord-Trøndelag
}

\author{
Lisa Aarhus $^{1}$, Ellen Kvestad ${ }^{1,2}$, Kristian Tambs ${ }^{1}$ og Bo Engdahl ${ }^{1}$ \\ 1) Divisjon for Psykisk helse, Nasjonalt folkehelseinstitutt \\ 2) Øre, nese og hals-avdelingen, Akershus universitetssykehus \\ Korrespondanse: Lisa Aarhus, Nasjonalt folkehelseinstitutt, $\mathrm{Pb} 4404$ Nydalen, 0403 Oslo \\ E-post: lisa.aarhus@fhi.no Telefon: 21078370
}

\section{INTRODUKSJON}

Hørselstap er et av de mest vanlige helseproblemene i den industrialiserte delen av verden. Om lag $10 \%$ av befolkningen har et hørselstap som er av betydning for kommunikasjon og denne andelen øker til $40 \%$ i befolkningen eldre enn 65 år. $80 \%$ av alle hørselstap finnes hos eldre (1). Aldersrelatert hørselstap (ARHT) eller presbyacusis er den vanligste årsaken til redusert hørsel. ARHT er en permanent reduksjon av hørselen som i hovedsak skyldes degenerasjon av blant annet indre hårceller $\mathrm{i}$ sneglehuset $\mathrm{i}$ det indre øret (1). Hørselstapet begynner i de høye frekvensene. I tillegg til redusert mulighet til å nyte musikk og andre lyder vi liker, kan hørselstap føre til sosial isolasjon, frustrasjon, avhengighet av andre og redusert livskvalitet (2).

På bakgrunn av hørselsmåling av et stort antall unge ørefriske personer har man definert normal høreterskel til $0 \mathrm{~dB}$. Verdens Helseorganisasjon (WHO) definerer hørselstap som gjennomsnittlige høreterskler over 25 $\mathrm{dB}$ i talefrekvensområdet $(0.5,1,2$ og $4 \mathrm{kHz})$ for det beste øret. Moderat hørselstap er definert som høreterskler over $40 \mathrm{~dB}$ og alvorlig hørseltap over $60 \mathrm{~dB}$. Forekomsten av hørselstap har vært vanskelig å sammenlikne på tvers av tidligere studier på grunn av ulike definisjoner av hørselstap og forskjeller i studiepopulasjon. I en stor ny oversiktsartikkel anbefaler man å bruke WHO sin definisjon av hørselstap i fremtidige epidemiologiske studier for lettere å kunne sammenlikne resultater (3).

Det er stor individuell variasjon i alder ved debut, progresjon og alvorlighetsgrad av ARHT. Studier av generasjonseffekt på aldershørselstap viser at tidligere generasjoner utviklet ARHT i større grad enn i dag (4). Dette kan indikere at ARHT ikke bare er en uunngåelig aldringsprosess. Effekten av faktorer som potensielt kan påvirke utviklingen av hørselstap, slik som støyeksponering, medikamentbruk, ørebetennelser, hodeskade, hjerte-karsykdom, diabetes og røyking har vært undersøkt $\mathrm{i}$ en rekke studier, men bortsett fra støyeksponering er det ikke funnet klare enkeltstående risikofaktorer. ARHT forårsakes sannsynligvis av en kombinasjon av genetisk disposisjon og akkumulering av støy, ototoksiske medikamenter og annen sykdom (5).

Eksperimentelle dyremodeller har vist at hårcellene $\mathrm{i}$ det indre øret hos blant annet atlanterhavstorsk har evnen til regenerasjon etter skade (6). Hårcellene i det indre øret hos mennesker kan ikke regenerere, og det finnes ingen kurativ behandling for aldersrelatert hør- selstap. Behandlingen vil være tilpasning av høreapparat, noe som for mange vil redusere plagene.

Med utgangspunkt i hørselstap hos eldre presenteres videre en oppsummering av noen tidligere publiserte resultater fra Hørselsundersøkelsen i Nord-Trøndelag 1995-1997.

\section{MATERIALE OG METODE}

Hørselsundersøkelsen i Nord-Trøndelag 1995-1997 inviterte alle personer over 19 år fra 17 av 23 kommuner i Nord-Trøndelag. 82141 ble invitert og 51975 personer deltok. Deltakelse blant eldre var 79\% $(\mathrm{n}=7201)$, $70 \%(\mathrm{n}=6347)$ og $42 \%(\mathrm{n}=1978)$ for henholdsvis alderen 60-69 år, 70-79 år, og 80-89 år. Rentoneaudiometri med luftledning ble utført $\mathrm{i}$ henhold til internasjonal standard (ISO 8253-1, 1989), for å finne høreterskelen i dB for frekvensene $0.25,0.5,1,2,3,4,6$ og $8 \mathrm{kHz}$. I tillegg besvarte deltakerne et spørreskjema som omhandlet ulike former for støyeksponering og andre risikofaktorer. Mer detaljert informasjon om materialet i Hørselsundersøkelsen er publisert tidligere (7).

\section{RESULTATER}

\section{Forekomst}

Hørselsundersøkelsen ble brukt til kartlegging av hørsel i ulike aldersgrupper. ARHT begynner allerede $i$ trettiårene for høye frekvenser og øker med alderen. Blant personer over 65 år har $62 \%$ et hørselstap. Tabell 1 viser forekomst av hørselstap for aldersgrupper over 60 år.

Tabell 1. Forekomst av mildt, moderat og alvorlig hørselstap (høreterskel midlet over $0,5,1,2$ og $4 \mathrm{kHz}$ på beste $ø$ re) i prosent i ulike aldersgrupper. For at forekomsten skal være representativ for den generelle populasjonen, er den veid $\mathrm{i}$ forhold til kjønn og alder basert på deltakelse.

\begin{tabular}{llccc}
\hline $\begin{array}{l}\text { Alder } \\
(\text { år })\end{array}$ & $\begin{array}{c}\text { Mildt } \\
(>25 \mathrm{~dB})\end{array}$ & $\begin{array}{c}\text { Moderat } \\
(>40 \mathrm{~dB})\end{array}$ & $\begin{array}{c}\text { Alvorlig } \\
(>60 \mathrm{~dB})\end{array}$ \\
\hline $60-69$ & Menn & 41 & 11 & 1 \\
$70-79$ & & 69 & 29 & 3 \\
$80-89$ & & 88 & 57 & 12 \\
\hline $60-69$ & Kvinner & 21 & 4 & 1 \\
$70-79$ & & 53 & 17 & 2 \\
$80-89$ & & 85 & 46 & 8 \\
\hline $60-69$ & \multirow{2}{*}{ Alle } & 31 & 7 & 1 \\
$70-79$ & & 60 & 22 & 3 \\
$80-89$ & & 86 & 50 & 9 \\
\hline
\end{tabular}




\section{Risikofaktorer}

Høy alder er klart viktigste risikofaktor for hørselstap. Alder alene forklarte 30-58\% av variasjonen i hørsel. Effekten av alder var størst for hørsel i høyfrekvensområdet. Til sammenlikning forklarte alle andre risikofaktorer i undersøkelsen tilsammen $6 \%$ av variasjonen i høyfrekvent hørsel hos eldre menn og $1 \%$ hos unge kvinner (8).

Arbeidsplassen kan være en viktig kilde til støyeksponering. Arbeid i mekanisk industri, verkstedindustri, bygg/anlegg, tungtransport, sjøfart/fiske og skogbruk var assosiert med redusert hørsel. Grad av hørselstap, kontrollert for andre forhold, økte med grad av støyeksponering. For menn eldre enn 64 år hadde de $2 \%$ med høyest eksponering for arbeidsstøy i gjennomsnitt $13 \mathrm{~dB}$ dårligere hørsel $(3 \mathrm{kHz})$ enn ueksponert gruppe, kontrollert for en rekke andre variabler. Nord-Trøndelag er et fylke hvor jakt tradisjonelt har stått sterkt og i undersøkelsen rapporterte $16 \%$ av menn og 2,5\% av kvinner eksponering for impulsstøy (eksplosjoner, skyting). I denne gruppen hadde menn over 64 år $\mathrm{i}$ gjennomsnitt $8 \mathrm{~dB}$ dårligere hørsel $(3-8 \mathrm{kHz})$ enn de som ikke rapporterte slik eksponering (7). Hos kvinner var det mindre forskjeller mellom eksponerte og ueksponerte. Vi fant ingen økt risiko for hørselstap forbundet med spilling i musikkorps eller band, bruk av bærbart stereoutstyr eller besøk på diskotek, rockekonserter og andre steder med høy musikk.

Tidligere sykehusinnleggelse på grunn av hodeskade predikerte små endringer $\mathrm{i}$ hørsel $\mathrm{i}$ alle frekvensområder. Gjentatte ørebetennelser i barndommen hadde også små effekter på hørselen og vi fant ingen kjønnsforskjeller. Beregnede effekter var imidlertid sterkere hos eldre enn hos yngre, opp til $12 \mathrm{~dB}$, til tross for at gjentatte ørebetennelser nesten bare forekommer hos barn (9).

Ved hjelp av et familiedesign ble det funnet en betydelig arvelighet av redusert hørsel i det arvelige faktorer forklarte $35 \%$ av variasjonen i hørsel i befolkningen (10).

\section{Konsekvenser}

Hørselstap påvirket rapport av symptomer på angst og depresjon, selvfølelse og generell livstilfredshet $i$ alle aldersgrupper i liten til moderat grad. Effekten var størst blant unge og middelaldrende, mens de knapt var målbare blant eldre over 65 år. Bruk av høreapparat ble ikke studert (11). Det ble ikke funnet økning i symptomer på angst og depresjon eller nedsatt generell livskvalitet hos ektefellen til personer med nedsatt hørsel, men tverrsnittsdesign er ikke optimalt for å studere denne typen effekter (12).

\section{KONKLUSJON}

Hørselstap er vanlig i den eldre delen av befolkningen, og er mer uttalt hos menn enn kvinner. Høy alder og genetisk disposisjon er de klart viktigste risikofaktorene for redusert hørsel. Støyeksponering kan øke progresjonen av hørselstap, mens tidligere hodeskade og ørebetennelse er av mindre betydning.

Forekomsten av ARHT vil øke i takt med den aldrende befolkningen. I fremtiden vil en godt utbygget og tilgjengelig hørselsomsorg være av stor betydning for å identifisere personer med hørselstap, formidle høreapparat og andre hørselstekniske hjelpemidler samt gi råd og veiledning.

\section{REFERANSER}

1. Gates GA, Mills JH. Presbycusis. Lancet 2005; 366 (9491): 1111-20.

2. Ciorba A, Bianchini C, Pelucchi S, Pastore A. The impact of hearing loss on the quality of life of elderly adults. Clin Interv Aging 2012; 7: 159-63.

3. Roth TN, Hanebuth D, Probst R. Prevalence of age-related hearing loss in Europe: a review. Eur Arch Otorhinolaryngol 2011; 268 (8): 1101-7.

4. Zhan W, Cruickshanks KJ, Klein BE, Klein R, Huang GH, Pankow JS, et al. Generational differences in the prevalence of hearing impairment in older adults. Am J Epidemiol 2010; 171 (2): 260-6.

5. Bielefeld EC, Tanaka C, Chen GD, Henderson D. Age-related hearing loss: is it a preventable condition? Hear Res 2010; 264 (1-2): 98-107.

6. Faucher K, Aas-Hansen O, Damsgard B, Laukli E, Stenklev NC. Damage and functional recovery of the Atlantic cod (Gadus morhua) inner ear hair cells following local injection of gentamicin. Int J Audiol 2009; 48 (7): 456-64.

7. Tambs K, Hoffman HJ, Borchgrevink HM, Holmen J, Engdahl B. Hearing loss induced by occupational and impulse noise: results on threshold shifts by frequencies, age and gender from the Nord-Trøndelag Hearing Loss Study. Int J Audiol 2006; 45 (5): 309-17.

8. Tambs K. Hearing loss caused by noise, otitis and head injuries. Tidsskr Nor Lageforen 2003; 123 (21): 3047-9.

9. Tambs K, Hoffman HJ, Engdahl B, Borchgrevink HM. Hearing loss associated with ear infections in NordTrøndelag, Norway. Ear Hear 2004; 25 (4): 388-96.

10. Kvestad E, Czajkowski N, Krog NH, Engdahl B, Tambs K. Heritability of hearing loss. Epidemiology 2012; 23 (2): 328-31.

11. Tambs K. Moderate effects of hearing loss on mental health and subjective well-being: results from the NordTrøndelag Hearing Loss Study. Psychosom Med 2004; 66 (5): 776-82.

12. Ask H, Krog NH, Tambs K. Impact of hearing impairment on spousal mental health: the Nord-Trøndelag Health Study. Eur J Public Health 2010; 20 (3): 271-5. 